\title{
Penelusuran Ciri Khas Musikal Lagu-Lagu Cianjuran Wanda Papantunan
}

\author{
Mustika Iman Zakaria S \\ Jurusan Karawitan, Fakultas Seni Pertunjukan \\ Institut Seni Budaya Indonesia Bandung \\ Jalan Buah Batu No 212, Kota Bandung, Jawa Barat \\ Email: mustikaizs@gmail.com
}

\begin{abstract}
The writing titled 'Musical Characteristics Search of Wanda Papantunan Cianjuran Songs' is a small part of the research conducted by the author with the title 'Inventory and Documenting of Cianjuran Songs In to Musical Notation, As the Initial Stage of The Study of The Aesthetic Value of Musical Cianjuran'. This paper aims to trace the musical characteristics of wanda songs by referencing the opinions of previous researchers and by conducting an analysis of the notation of wanda songs. In the analysis of song notation, identification of musical elements was done, the results of which complemented the musical description of wanda songs from previous researchers with musical indicators. Thus from the results of the identification process, conclusions are produced about the musical characteristics of wanda songs through musical indicators related to the melody of the song, the accompaniment of the song, and the structure of the presentation of the song.
\end{abstract}

Keywords: characteristics, song, cianjuran, wanda, papantunan.

\begin{abstract}
ABSTRAK
Tulisan berjudul Penelusuran Ciri Khas Musikal Lagu-lagu Cianjuran Wanda Papantunan ini merupakan sebagian kecil dari penelitian yang dilakukan oleh penulis dengan judul Inventarisasi dan Pendokumentasian Lagu-Lagu Cianjuran ke dalam Bentuk Notasi Musik, Sebagai Tahap Awal Kajian Nilai Estetika Musikal Cianjuran. Dalam tulisan ini, dibahas mengenai penelusuran ciri khas musikal lagu-lagu wanda papantunan dengan merujuk pendapat para peneliti sebelumnya dan dengan melakukan analisis notasi lagu-lagu wanda papantunan. Dalam analisis notasi lagu, dilakukan pengidentifikasian unsur-unsur musikal yang hasilnya dapat melengkapi uraian ciri khas musikal lagu-lagu wanda papantunan dari para peneliti sebelumnya dengan indikatorindikator musikal. Dengan demikian dari hasil proses pengidentifikasian tersebut, dihasilkan kesimpulan mengenai ciri khas musikal lagu-lagu cianjuran wanda papantunan melalui idikatorindikator musikal yang berkaitan dengan melodi lagu, iringan lagu, dan struktur penyajian lagu.
\end{abstract}

Kata kunci: ciri khas, lagu, cianjuran, wanda, papantunan.

\section{PENDAHULUAN}

Cianjuran adalah sebentuk seni yang merupakan perpaduan antara vokal dengan instrumental (Sukanda dkk, 2016, hlm. 17). Vokal (sekar) disajikan oleh vokalis pria dan wanita dan instrumental (gending) disajikan dengan menggunakan alat musik kacapi parahu/ kacapi indung, kacapi rincik, suling, dan rebab atau biola.

Cianjuran dikenal juga dengan istilah 
sebutan seni mamaos, terutama di kalangan seniman di Kabupaten Cianjur. Disebut seni mamaos, karena berkaitan dengan salah satu cikal pembentuk seni tersebut, yakni dari seni mamaca (Hendrayana dkk, 2020, hlm. 421).

Di dalam seni cianjuran dikenal dengan istilah wanda atau pengelompokan lagu berdasarkan latar belakang sejarah penciptaan dan ciri khas musikalnya. Wanda yang terdapat di dalam cianjuran, di antaranya adalah wanda papantunan, wanda jejemplangan, wanda dedegungan, wanda rarancagan, wanda kakawen, dan wanda panambih. Berkaitan dengan latar belakang sejarah penciptaannya, wanda-wanda tersebut terbentuk dari unsur-unsur musikal kesenian yang telah ada sebelum lahirnya seni cianjuran, yakni wanda papantunan dan jejemplangan terbentuk dari unsur musikal seni pantun, wanda dedegungan dari seni degung klasik, wanda rarancagan dari seni tembang buhun, wanda kakawen dari seni wayang golek, serta wanda panambih dari seni gamelan sunda.

Berkaitan dengan ciri khas musikal dari wanda-wanda tersebut, hingga saat ini masih menjadi bahan diskusi yang alot di kalangan tokoh dan seniman seni cianjuran. Baik tokoh maupun seniman cianjuran, menggambarkan ciri khas musikal wanda-wanda tersebut dengan istilah sari pantun (intisari pantun), sari jemplang, sari degung, sari rancag, sari kakawen, dan sari panambih. Namun seiring dengan kemunculan dari istilah tersebut tidak disertai oleh indikator-indikator yang jelas terkait dengan aspek-aspek musikal yang menjadi ciri khas dari wanda-wanda tersebut.

Jika Kutha Ratna (2015, hlm. 143) mencontohkan ciri khas karya sastra adalah bahasa, maka jika berbicara mengenai ciri khas musikal karya lagu adalah musik. Kendati di dalam suatu lagu terdapat juga aspek sastra, tetapi hal tersebut menjadi bahasan tersendiri, karena juga memiliki metode dan pendekatan yang berbeda dengan kajian atau penelusuran aspek musikal. Demikian juga dengan lagulagu cianjuran, jika kajiannya mengenai aspek musikal, maka sudah tentu aspek-aspek yang diuraikan adalah yang berkaitan dengan musikal.

Sebuah lagu atau nyanyian merupakan sebuah karya musik. Secara umum, unsurunsur yang terdapat dalam sebuah lagu adalah bentuk, kalimat, dan motif (EdmundKarl, 2011, hlm. 1-3). Pendapat Edmund-Karl dalam hal ini, banyak memberikan gambaran dalam upaya untuk menelusuri aspek musikal lagu-lagu cianjuran yang kemungkinan besar menjadi ciri khas dari suatu wanda dalam cianjuran.

Ciri khas musikal dari wanda-wanda dalam cianjuran menjadi hal yang menarik dan penting untuk ditelusuri, sebagai langkah awal dalam kajian nilai estetika musikal dari materi lagu cianjuran. Selain hal tersebut, penelusuran ciri khas musikal dari wandawanda tersebut juga sangat bermanfaat sebagai kisi-kisi dalam penciptaan lagu-lagu baru cianjuran, pengembangan lagu-lagu cianjuran, dan sebagai media pembelajaran bagi guru atau pelatih dalam memberikan materi lagulagu cianjuran.

Dengan segala keterbatasan, dalam tulisan ini penulis membahas terlebih dahulu mengenai penelusuran ciri khas musikal dari salah satu wanda dalam cianjuran, yakni wanda papantunan. Penelusuran ciri khas musikal tersebut dilakukan dengan merujuk pendapat 
para peneliti sebelumnya mengenai ciri khas wanda papantunan dan melalui analisis notasi lagu-lagu wanda papantunan. Dalam analisis notasi lagu, dilakukan penandaan unsur-unsur musikal terutama melodi yang seringkali muncul dalam tiap lagu wanda papantuan. Dengan demikian hasil yang diharapkan dari penelusuran ini adalah teridentifikasinya ciriciri musikal khusus dari lagu wanda papantunan yang diindikasikan oleh melodi lagu, iringan, dan struktur penyajian lagu.

\section{METODE}

Metode yang digunakan dalam penelitian ini adalah metode kualitatif. Menurut Sugiyono (2012, hlm. 222), metode penelitian kualitatif sebagai human instrumen berfungsi menetapkan fokus penelitian, memilih informan sebagai sumber data, melakukan pengumpulan data, menilai kualitas data, analisis data, menafsirkan data, dan membuat kesimpulan atas temuan yang bisa dipertanggujawabkan secara ilmiah.

Berpijak dari penjelasan tersebut, langkah kerja yang dilakukan dalam kajian ini dibagi ke dalam dua tahap, yaitu: kerja lapangan (filedwork) dan kerja di atas meja (deskwork). Pada tahapan kerja lapangan peneliti melakukan studi pustaka, studi dokumentasi audio dan audio-visual, observasi, dan wawancara, untuk menginventarisasi lagulagu cianjuran, wanda papantuan. Selanjutnya, pada tahapan kerja di atas meja, peneliti mengolah, menganalisis, dan menafsirkan data yang telah dikumpulkan melalui kerja lapangan ke dalam sebuah bentuk notasi musik.
Notasi musik tersebut di atas menjadi bahan analisa untuk mengidentifikasi bentuk, kalimat, dan motif lagu-lagu cianjuran wanda papantunan. Setelah di temukan bentuk, kalimat, danmotiflagu darilagu-lagucianjuran, wanda papantunan, kemudian temuan-temuan tersebut digunakan untuk melengkapi uraian atau pendapat dari pendapat para tokoh mengenai ciri khas musikal lagu-lagu cianjuran, wanda papantunan.

\section{HASIL DAN PEMBAHASAN}

\section{Wanda Papantunan}

Wanda papantunan merupakan salah satu kelompok lagu dalam seni cianjuran yang terdiri dari lagu-lagu yang sumber penciptaannya dari seni pantun. Sebelum munculnya istilah papantunan, sebagian tokoh di Cianjur menyebut lagu-lagu yang terbentuk dari seni pantun tersebut dengan sebutan pantun dan ada juga yang menyebutnya tembang pajajaran. Disebut seni pantun, diduga karena berhubungan dengan cikal bekal seni pembentuknya, disebut tembang pajajaran karena berhubungan dengan isi cerita dari rumpaka atau syair lagu-lagunya.

Bila dilihat dari munculnya istilah tembang pajajaran, tentunya tidak semua seni pantun menjadi sumber penciptaan lagu cianjuran. Hal tersebut karena cerita dalam seni pantun itu banyak ragamnya, dan salah satu isi ceritanya adalah mengenai kerajaan Pajajaran. Dari sejumlah judul dalam seni pantun dengan isi cerita mengenai kerajaan Pajajaran, seni pantun yang berjudul Mundinglaya di Kusumah menjadi sumber penciptaan bagi sejumlah lagu dalam tembang sunda cianjuran yang termasuk 
Tabel 1. Lagu-lagu Wanda Papantunan

\begin{tabular}{|c|c|c|}
\hline No & Judul Lagu & Kategori Lagu \\
\hline 1 & Banjar Karang & Lagu Non-Pokok \\
\hline 2 & Balagenyat & Lagu Non-Pokok \\
\hline 3 & Budak Leungit & Lagu Non-Pokok \\
\hline 4 & Candrawulan & Lagu Pokok \\
\hline 5 & $\begin{array}{l}\text { Dangdanggula } \\
\text { Paniisan }\end{array}$ & Lagu Non-Pokok \\
\hline 6 & $\begin{array}{l}\text { Dangiang } \\
\text { Pantun }\end{array}$ & Lagu Non-Pokok \\
\hline 7 & Gelang Gading & $\begin{array}{l}\text { Papantunan } \\
\text { Khusus }\end{array}$ \\
\hline 8 & Goyong & Lagu Non-Pokok \\
\hline 9 & Goyong Petit & Lagu Non-Pokok \\
\hline 10 & Kaleon & Lagu Pokok \\
\hline 11 & Kinanti Layar & Lagu Non-Pokok \\
\hline 12 & Kunosari/ Rajah & $\begin{array}{l}\text { Papantunan } \\
\text { Khusus }\end{array}$ \\
\hline 13 & Layar Putri & Lagu Pokok \\
\hline 14 & Mandalagita & Lagu Non-Pokok \\
\hline 15 & Mangu Mangu & Lagu Pokok \\
\hline 16 & Manyeuseup & Lagu Pokok \\
\hline 17 & Mupu Kembang & Lagu Pokok \\
\hline 18 & Nataan Gunung & Lagu Pokok \\
\hline 19 & Pangapungan & Lagu Pokok \\
\hline 20 & Papatet & Lagu Pokok \\
\hline 21 & Papatet Kaum & Lagu Non-Pokok \\
\hline 22 & Papatet Ratu & Lagu Pokok \\
\hline 23 & Putri Ninun & Lagu Pokok \\
\hline 24 & Rajamantri & Lagu Pokok \\
\hline 25 & Randegan & Lagu Pokok \\
\hline 26 & $\begin{array}{l}\text { Randegan } \\
\text { Gancang }\end{array}$ & Lagu Pokok \\
\hline 27 & Salakadomas & Lagu Pokok \\
\hline 28 & Tali Rasa & Lagu Non-Pokok \\
\hline 29 & Taman Endah & Lagu Non-Pokok \\
\hline 30 & Tatalegongan & Lagu Pokok \\
\hline 31 & Tejamantri & Lagu Non-Pokok \\
\hline
\end{tabular}

ke dalam wanda papantunan (Sukanda dkk, 2016, hlm. 31),

Lagu-lagu wanda papantunan berjumlah 31 judul lagu. Lagu-lagu tersebut dibagi menjadi dua kategori lagu berdasarkan nama judul lagunya, yakni lagu pokok dan lagu non-pokok. Lagu pokok merupakan lagu-lagu yang nama judulnya diambil dari nama tokoh maupun lukisan dari suatu momen dalam cerita pantun Mundinglaya di kusumah dan lagu non-pokok merupakan lagu-lagu yang nama judulnya tidak ada kaitannya dengan nama tokoh maupun lukisan suatu peristiwa dalam cerita pantun Mundinglaya di kusumah. Selain dari dua kategori lagu tersebut, terdapat juga kategori lagu papantunan khusus, yakni lagu wanda papantunan yang memiliki beberapa perbedaan aspek musikal dengan lagu-lagu wanda papantunan pada umumnya, namun sumber materi lagunya berasal dari seni pantun (Sukanda dkk, 2016, hlm. 30, 72-92). Berikut di bawah ini adalah lagu-lagu yang termasuk ke dalam wanda papatunan.

\section{Ciri Khas Musikal Lagu-Lagu Wanda Papantunan}

Ciri khas musikal lagu-lagu wanda papantunan, secara umum telah dijelaskan oleh Sukanda dkk (2016, hlm. 61-70), yakni; 1) Berlaras pelog, 2) Memiliki lagu pembuka papantunan, 3) Memiliki irama/ wirahma yang tidak tetap, 4) Menggunakan nada 2 (Mi) da 5 (La) secara konsisten dalam melodi lagu, 5) Akhir suatu lagu selalu jatuh pada nada 5 (La), dan 6) Diringi oleh kacapi dengan petikan accord dengan nada pokok 5 (La) dan 2 (Mi).

Selain dari Sukanda dkk, Wiratmadja (1996, hlm. 38) juga menjelaskan mengenai 
ciri-ciri khas musikal dari wanda papantunan, yakni; 1) Tesisnya jatuh pada nada-nada 2 (Mi) dan 5 (La) laras pelog, 2) Kecuali lagu Papatet, lagu-lagu wanda ini (papantunan) memiliki gelenyu dan cara pirigan/ iringan tersendiri, dan 3) Cara pirigan (iringan) kacapinya disintreuk dan dikemprang.

Uraian mengenai ciri khas musikal lagulagu wanda papantunan dariSukanda, dkk, serta Wiratmadja di atas pada dasarnya memiliki banyak persamaan. Apabila pendapat atau uraian tersebut dirangkum menjadi sebuah kesatuan dengan ditambah beberapa poin hasil analisa penulis, maka ciri khas musikal lagu-lagu wanda papantunan adalah; 1) Berlaras pelog, 2) Memiliki bentuk musikal sekar wirahma merdika, 3) Memiliki kalimat lagu pembuka, 4) Melodi lagu didominasi oleh penggunaan nada 2 (Mi) dan 5 (La), 5) Memiliki satu kalimat melodi khas dengan gaya melodi silabis, 6) Memiliki struktur ornamentasi/ dongkari yang khas, 7) Memiliki kalimat melodi lagu tambahan di suatu bagian akhir frase melodi lagu, 8) Memiliki gelenyu/ intro yang bawakan oleh musik pengiring, dan 9) Diiringi oleh kacapi dengan menggunakan pola iringan dikemprang.

Melengkapi penjelasan poin-poin ciri khas musikal lagu-lagu wanda papantunan tersebut, berikut di bawah ini uraiannya:

\section{Berlaras Pelog}

Laras pelog dan degung bagi sebagian seniman dianggap sebagai laras yang sama, bahkan ada yang menyebutnya dengan laras pelog degung. Namun, menurut teori laras (Kusumadinata, 1969, hlm. 31) dijelaskan bahwa laras pelog dan laras degung memiliki

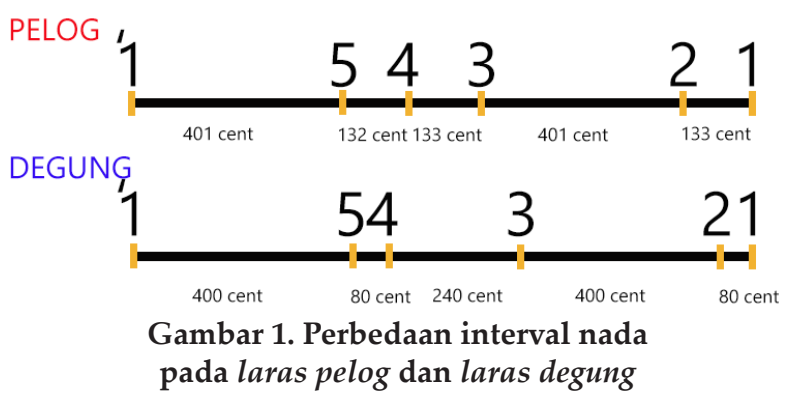

Tabel 2. Skema Rakitan Laras Salendro dan Laras Turunannya

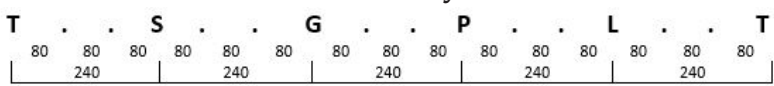

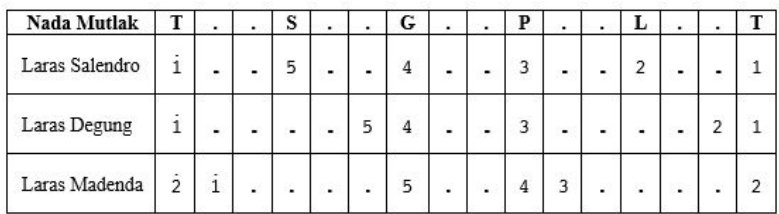

Tabel 3. Skema Rakitan Laras Pelog dan Laras Turunannya

$\underbrace{T}_{134} \int_{267}^{0} \underbrace{S}_{132} \underbrace{G}_{133} \underbrace{P}_{266} \underbrace{U}_{135} \underbrace{L}_{133} T$

\begin{tabular}{|l|c|c|c|c|c|c|c|c|c|}
\hline Nada Mutlak & O & S & G & P & U & L & T & 0 & S \\
\hline Surupan Jawar &. & 5 & 4 & 3 &. & 2 & 1 &. & 5 \\
\hline Surupan Liwung &. & 2 & 1 &. & 5 & 4 & 3 &. & 2 \\
\hline Surupan Sorog & 3 &. & 2 & 1 &. & 5 & 4 & 3 &. \\
\hline
\end{tabular}

perbedaan interval nada-nada yang signifikan. Perbedaan interval nada-nada tersebut bisa dilihat pada gambar 1.

Dalam teori laras, pelog dikategorikan sebagai rakitan laras dan disandingkan dengan rakitan laras Salendro. Rakitan laras pelog melahirkan laras pelog yang terbagi ke dalam beberapa surupan, yaitu: liwung, jawar, dan sorog. Sedangkan rakitan laras salendro melahirkan tiga laras, yaitu: salendro, degung, dan madenda yang masing-masing larasnya terbagi ke dalam beberapa surupan. Sehingga dapat disimpulkan bahwa secara teoretis terdapat empat laras dalam Karawitan Sunda, yaitu: pelog, salendro, degung, dan madenda.

Perbedaan nilai interval dan pembentukan laras dari masing-masing rakitan laras, 


\section{BALAGENYAT}

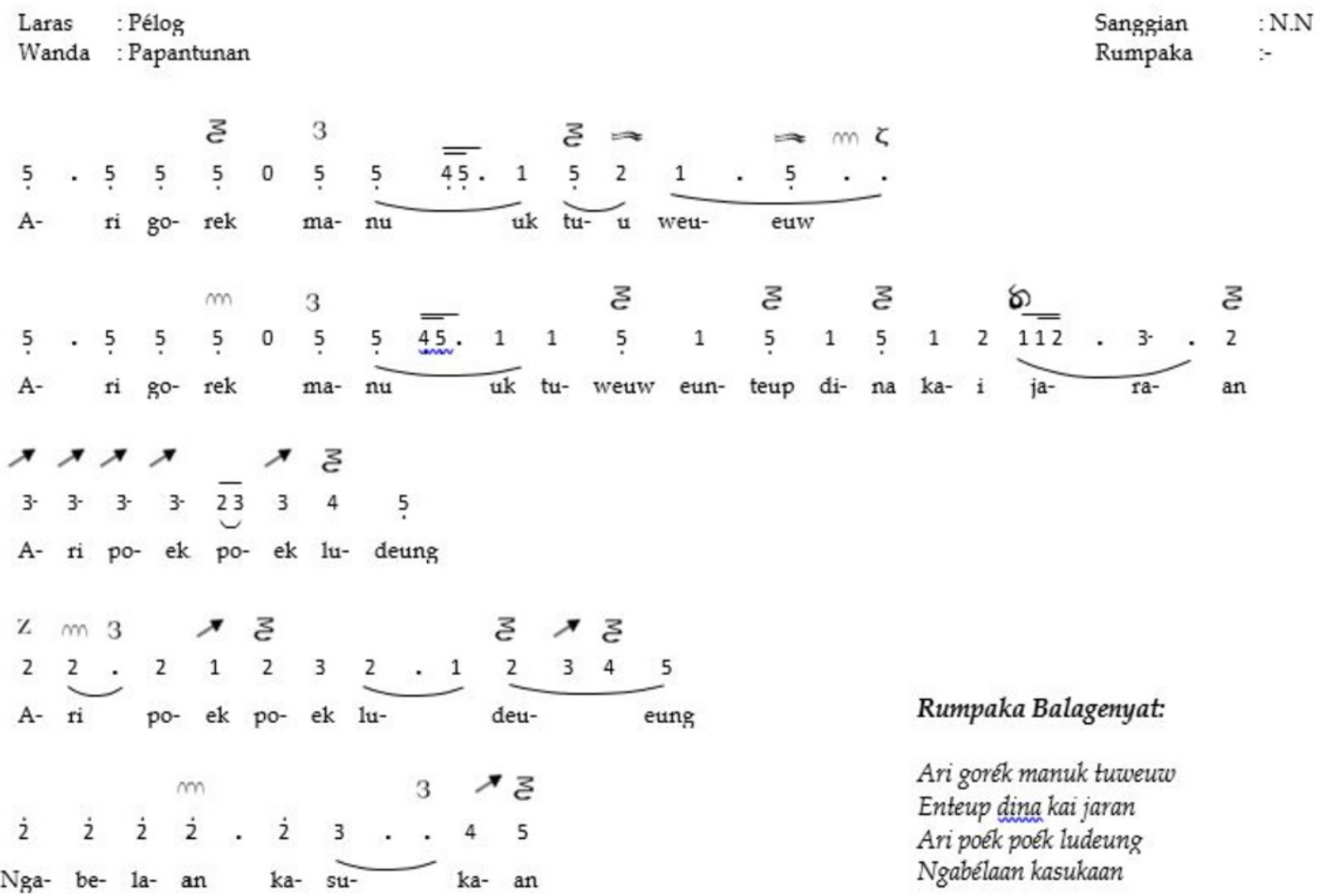

Gambar 2. Notasi Lagu Balagenyat

bisa dilihat pada tabel 2 dan 3.

Sampai saat ini belum bisa diketahui secara pasti alasan dari penyebutan laras pelog atau laras pelog degung terhadap laras degung oleh sebagian seniman cianjuran. Namun, apabila melihat acuan nada dasar dan laras pada lagu-lagu wanda papantunan yang bersumber pada nada-nada suling lubang enam dan atau suling lubang empat (suling degung), maka dapat dipastikan bahwa laras yang digunakan dalam lagu-lagu wanda papantunan adalah laras degung. Mengingat suling lubang enam dan suling lubang empat (suling degung) hanya digunakan dalam kesenian yang menggunakan waditra berlaras degung, seperti gamelan degung, dan tidak digunakan untuk mengiringi kesenian yang menggunakan waditra berlaras pelog, seperti gamelan pelog.
2. Memiliki Bentuk Musikal Sekar Wirahma Merdika

Sekar yaitu sebagai seninya dari janaswara (vokal. Sekar dibagi menjadi dua golongan pokok, yakni sekar tandak dan sekar wirahma merdika. Lagu yang termasuk kepada sekar tandak adalah seluruh lagu yang mempunyai irama atau ketukan yang tetap (tandak artinya tetap), dalam istilah asing disebut rhythmical song. Sekar tandak dalam istilah popular disebut kawih, karena sifatnya tandak (tetap) dan mempunyai ketukan, atau rhytme (wirahma), maka penulisannya bisa dilakukan dengan pasti. Gerakannya bisa ditentukan, cepat lambatnya suatu suku nada bisa ditentukan, panjang-pendeknya suatu nadapun bisa ditentukan (dalam istilah musik disebut dengan harga nada-value) (Natapradja, 2003, hlm. 72). 
Sekar wirahma merdika adalah golongan lagu yang tidak mempunyai ketukan, berirama bebas, tetapi ada aturan-aturan panjang-pendek yang tertentu yang tidak bisa dituliskan dengan sistem titi-laras. Penentuan panjang-pendeknya satu nada hanya bisa diajarkan secara lisan verbal atau oral dari seorang guru ke murid. Inilah golongan yang pada dunia seni suara Sunda disebut tembang dan di Jawa disebut macapat (Natapradja, 2003, hlm. 73-74)

Jika melihat uraian di atas, lagulagu wanda papantunan termasuk ke dalam golongan sekar wirahma merdika. Lagu-lagu wanda papantunan dalam hal ini tidak memiliki ketukan dan birama yang tetap, tetapi masih memiliki aturan aturan panjang-pendek dalam membawakan lagunya. Lagu-lagu yang termasuk ke dalam golongan sekar wirahma merdika, biasanya ditulis dalam notasi lagu dengan tidak menggunakan lambang garis matra, seperti contohnya dalam notasi lagu Balagenyat (lihat gambar 2).

\section{Memiliki Kalimat Lagu Pembuka}

Kalimat lagu pembuka dalam lagulagu wanda papantunan dikenal dengan istilah narangtang pantun. Narangtang pantun (vokal); merupakan sebuah istilah yang dipinjam dari istilah pola tabuhan kacapi untuk menunjukan sebuah kalimat melodi pembuka yang khusus terdapat dalam wanda papantunan, biasanya dilantunkan sebelum sajian suatu lagu utama dalam wanda papantunan. Selain disebut dengan istilah narangtang pantun, ada juga yang menyebutnya dengan istilah daweung. Narangtang pantun dibedakan menjadi dua jenis berdasarkan pendek dan

\section{Narangtang Pantun (Pondok)}

Laras: Degung

3. 3.
Da- Weu- eu- eung di a ja lu u- deu eur

Gambar 3. Notasi Melodi Narangtang Pantun Pondok Narangtang Pantun (Panjang)

Laras: Degung

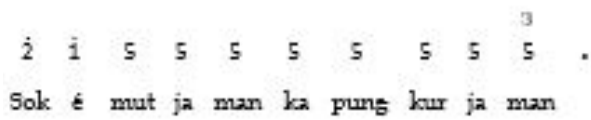

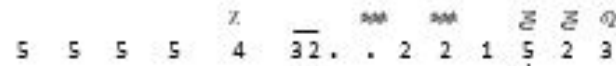

Pa- ja- ja- $\operatorname{ran} \operatorname{mux} b_{2}$ a a- $-a$ a a a

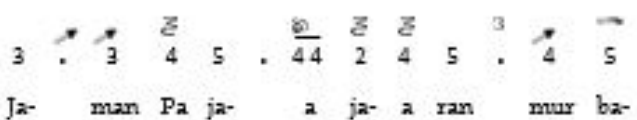

Gambar 4. Notasi Melodi Narangtang Pantun Panjang panjangnya kalimat melodi lagu. Pertama adalah narangtang pondok, dan yang kedua adalah narangtang panjang. Contoh melodi dan rumpaka narangtang pantun dapat dilihat pada gambar 3 dan 4 .

Selain dari rumpaka yang terdapat dalam notasi tersebut, ada juga beberapa rumpaka dalam narangtag pantun yang biasa digunakan oleh para juru mamaos/panembang, seperti contohnya, rumpaka narangtang pondok; Daweung diajar ludeung, Bandung heurin ku tangtung, Gusti abdi antosan, Gunung tanpa tutugan, Itu gunung naon, dan lain-lain (biasanya disesuaikan dengan isi atau rumpakal syair lagu yang akan dilantunkan), rumpaka narangtang panjang; Sok emut jaman kapungkur Jaman Pajajaran murba, Mukakeun panto bangongong Jalan gede sasapuan nyanggakeun balungbang timur caang bulan opat welas, dan lain-lain (biasanya disesuaikan dengan isi rumpaka lagu yang akan dilantunkan). 


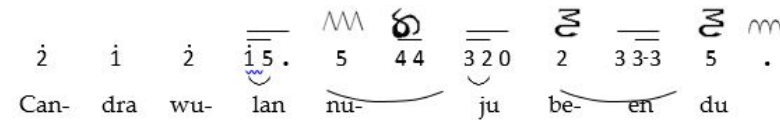

Gambar 5. Contoh Alur Melodi Pada Kalimat

Pertama Lagu-Lagu Wanda Papantunan

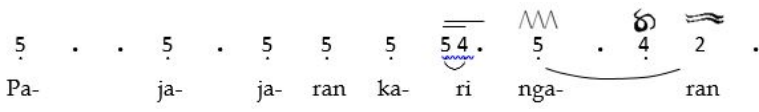

Gambar 6. Contoh Alur Melodi Pada Kalimat

Pertama Lagu-Lagu Wanda Papantunan

4. Melodi Lagu Didominasi oleh Penggunaan Nada 2 (Mi) dan 5 (La).

Dalam satu Kalimat melodi lagu di bagian awal hingga tengah, biasanya diawali oleh nada 2 (Mi) dan diakhiri oleh nada 5 (La), contohnya seperti yang terdapat dalam lagu Candrawulan, laras degung (lihat gambar 5).

Ada juga satu kalimat melodi lagu di bagian awal hingga tengah yang diawali oleh nada 5 (La) dan diakhiri oleh nada 2 (Mi), contohnya seperti yang terdapat dalam lagu Papatet, laras degung (lihat gambar 6).

Kalimat lagu terakhir pada bagian lagulagu wanda papantunan selalu jatuh kepada nada 5 (La), contohnya seperti yang terdapat dalam lagu Papatet Ratu dan Balagenyat (lihat gambar 7 dan 8).

5. Memiliki Satu Kalimat Melodi Khas dengan Gaya Melodi Silabis

Di dalam lagu-lagu tembang sunda cianjuran, terdapat suatu gaya melodi lagu di mana satu suku kata memiliki satu nada atau biasa disebut dengan istilah silabis, dan satu suku kata memiliki dari dua nada atau lebih atau biasa disebut dengan istilah melismatis. Oleh karena itu, tidak heran apabila di dalam penulisan notasi terdapat kombinasi penggunaan antara melodi yang menggunakan beberapa nada untuk satu suku kata dengan melodi yang menggunakan satu nada untuk satu suku kata.

Dalam melodi lagu-lagu wanda papantunan sering ditemukan kemunculan satu melodi silabis khas yang terletak di bagian tengah menjelang akhir atau terletak sebelum kalimat lagu paling akhir, yang menjadi salah satu ciri khas melodi lagu wanda papantunan. Berikut di bawah ini adalah contoh dari kalimat melodi lagu tersebut, yang terdapat dalam notasi lagu dengan tanda kotak (lihat gambar 9).

Selain terdapat dalam lagu Papatet Ratu, kalimat melodi tersebutpun dapat ditemukan dalam lagu Dangdanggula Paniisan, Dangiang Pantun, Mandalagita, Mangu-Mangu, Nataan Gunung, Papatet Kaum, Papatet Ratu, Salaka Domas, Taman Endah, dan Tejamantri.

6. Memiliki Struktur Ornamentasi/ Dongkari Yang Khas

Menurut Rosliani (dalam Hermawan, 2014, hlm. 27-30), di dalam seni cianjuran terdapat 19 jenis ornamentasi lagu/ dongkari sebagai hiasan melodi dasar lagu.

Pada dasarnya ornamentasi/ dongkari yang terdapat di cianjuran hampir digunakan semuanya di setiap lagu dan wanda. Namun yang paling signifikan membedakannya di setiap wanda adalah struktur dongkari. Di dalam wanda papantunan sendiri terdapat struktur dongkari yang khas yang terapat di dalam suatu frase melodi lagu, seperti contohnya penggunaan dongkari reureueus $(m)$ atau riak $(m)$ dan cacag ( $\approx$ ) yang diakhiri oleh jekluk $(\sqrt{ })$ yang terdapat di akhir frase melodi di bagian awal atau tengah lagu, seperti contohnya dalam lagu Papatet, laras degung (lihat gambar 10). 

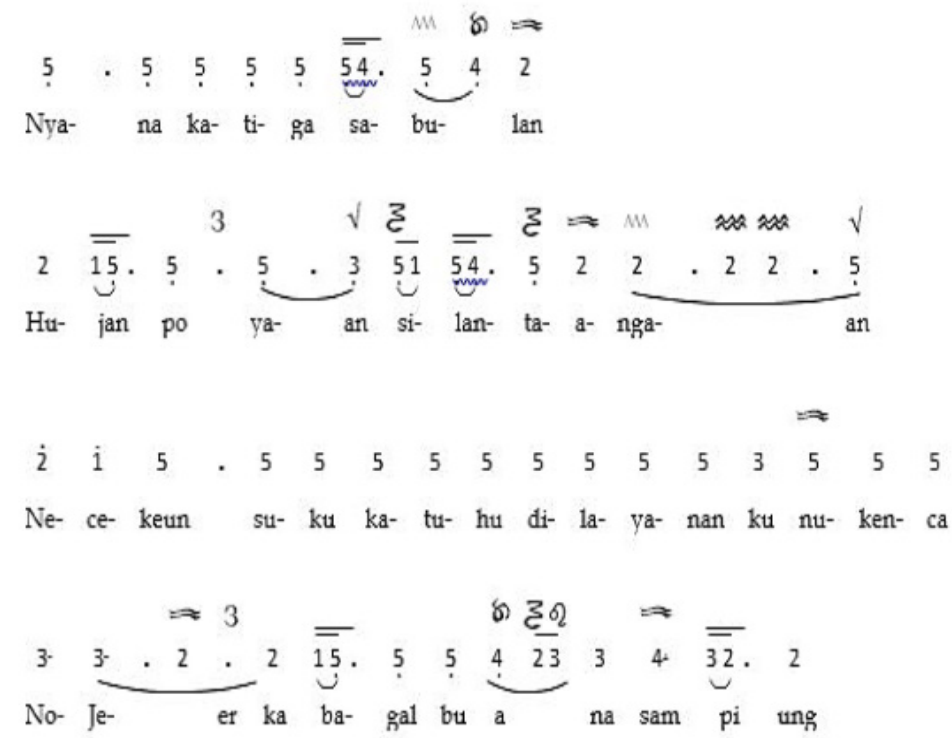

Rumpaka Papatet Ratu:

\begin{tabular}{|c|c|c|c|c|c|c|c|c|}
\hline 7. & MM & $\delta$ & 3 & & 8 & $=$ & 3 & \\
\hline 2 & 2 & 1 & 4 & 5 & $\overline{44}$ & $\overline{32}$. & 4 & 5 \\
\hline $\mathrm{Me}-$ & na & & ak & nu- & & nga- & pu- & ung \\
\hline
\end{tabular}

Nyana katiga sabulan Hujan poyan silantangan Nécekeun suku katuhu Dilayanan ku nu kénca Nojer ka bagal buana Sampiung ménak nu ngapung

Gambar 7. Contoh Kalimat Melodi Terakhir Lagu Wanda Papantunan

\section{BALAGENYAT}

$$
\begin{array}{ll}
\text { Laras } & : \text { Pélog } \\
\text { Wanda } & \text { : Papantunan }
\end{array}
$$
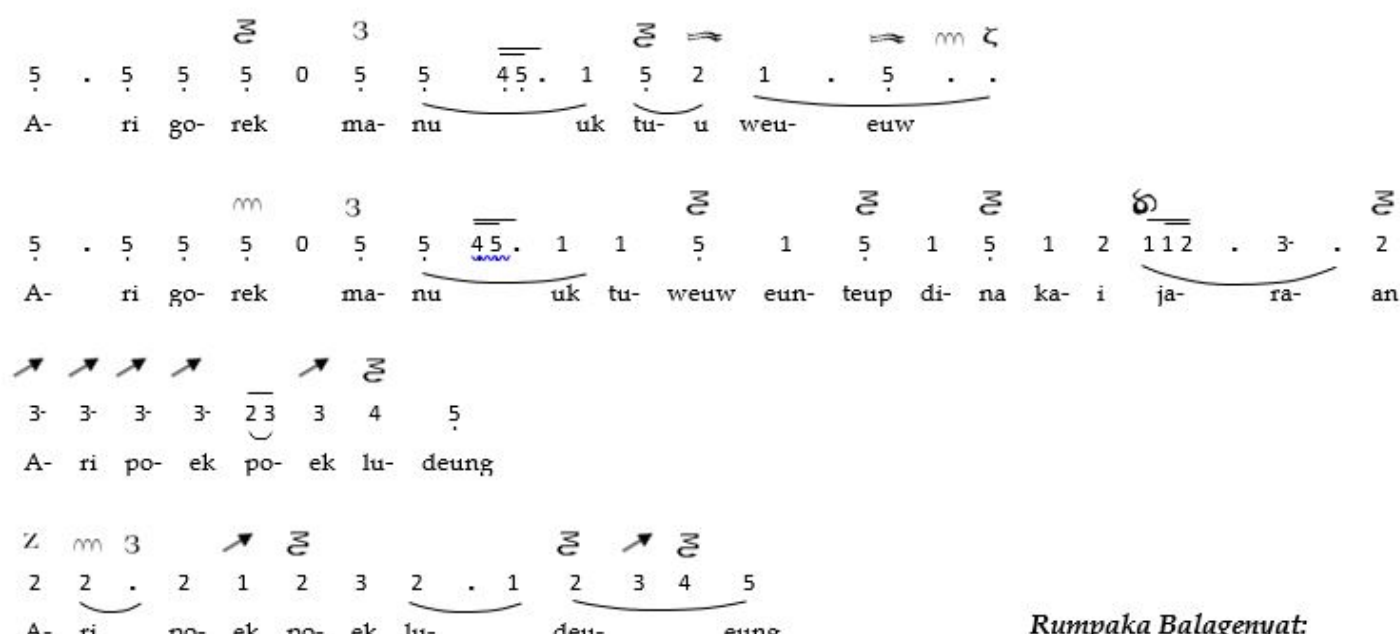

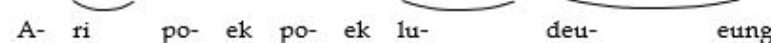

Rumpaka Balagenyat:

Ari gorék manuk tuweuw

Enteup dina kai jaran

Ari poek poék ludeung

Ngabélaan kasukaan

Gambar 8. Kalimat Melodi Terakhir Lagu Balagenyat 


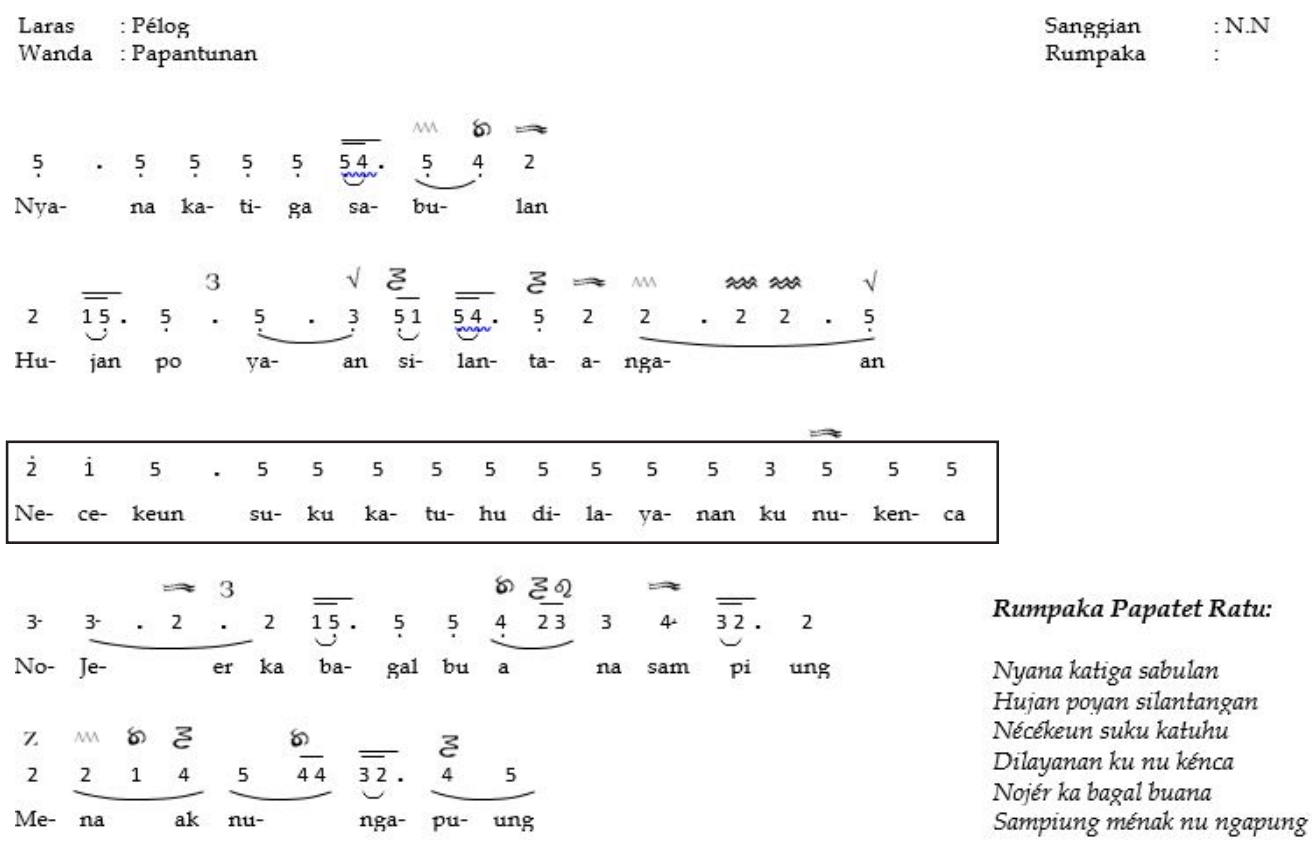

Gambar 9. Contoh Kalimat Melodi Silabis Khas Wanda Papantunan

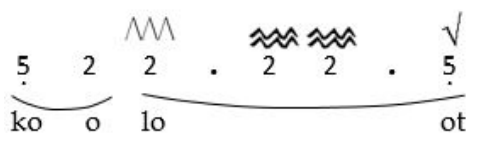

Gambar 10. Contoh Struktur Dongkari Khas Wanda Papantunan

Struktur dongkari tersebut di atas, terdapat juga dalam lagu Dangdangula Paniisan, Dangiang Pantun, Goyong, Mupu Kembang, Pangapungan, Papatet Ratu, Rajamantri, Randegan, Tali Rasa, dan Taman Endah.

Selanjutnya adalah struktur dongkari baledog ( $\rightarrow$ ) yang diakhiri oleh dongkari gibeg ( 3 ) yang biasanya terdapat dalam frase akhir lagu, seperti contohnya di dalam lagu Papatet (lihat gambar 11).

Struktur dongkari tersebut di atas, terdapat juga dalam lagu Balagenyat, Dangdanggula Paniisan, Goyong, Goyong Petit, Mandalagita, Mangu-mangu, Manyeuseup, Mupu Kembang, Nataan Gunung, Pangapungan, Papatet kaum, Papatet Ratu, Randegan Gancang, Salaka Domas, Tali Rasa, dan Teja Mantri.

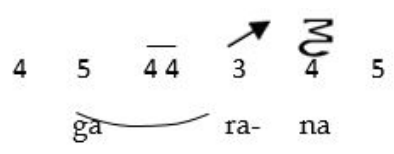

Gambar 11. Contoh Struktur Dongkari Khas Wanda Papantunan

7. Memiliki Kalimat Melodi Lagu Tambahan Di Suatu Bagian Akhir Frase Melodi Lagu.

Dalam lagu-lagu wanda papantunan seringkaliditemukankalimatmeloditambahan di luar melodi lagu uatama, yang menurut beberapa seniman berfungsi sebagai penegas rasa melodi lagu. Kendati begitu, dalam praktek menyajikan lagu wanda papantunan, ada yang menyajikan kalimat tambahan tersebut ada juga yang tidak. Kalimat melodi tambahan tersebut biasanya menggunakan nada 5 (La) dengan rumpaka 'raden', 'juragan', 'gening', dan kata-kata lain yang dianggap memiliki makna yang berhubungan dengan rumpaka lagu di belakangnya.

Contoh kalimat melodi:

$\begin{array}{ccc}\underset{\text { dalam rumpaka }}{\text { 'Raden' }} & 5 & 5 \\ & \text { ra } & \text { den }\end{array}$.




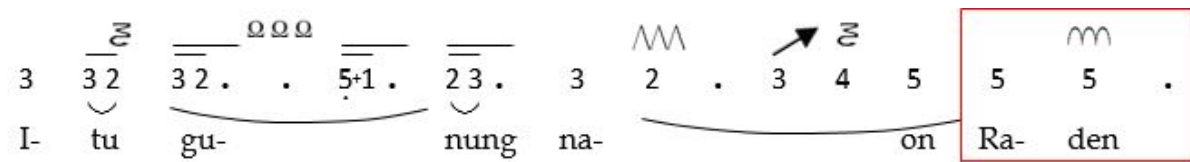

Gambar 12. Contoh Kalimat Melodi Lagu Tambahan Wanda Papantunan

\begin{tabular}{|c|c|c|c|c|c|c|c|}
\hline \multirow{2}{*}{\multicolumn{2}{|c|}{ Laras: Pelog }} & \multirow{2}{*}{$=$} & \multicolumn{3}{|c|}{ Gelenyu Papatet } & \multirow{3}{*}{$\overline{\overline{34} \overline{54}}$} & \multirow{3}{*}{$\overline{5 \overline{23}}$} \\
\hline & & & \multirow{2}{*}{$\overline{\overline{3325}}$} & \multirow{2}{*}{$\overline{\overline{4323}}$} & \multirow{2}{*}{$\overline{\overline{22}} \overline{32}$} & & \\
\hline 223 & 2232 & 5432 & & & & & \\
\hline & & & & $\overline{10}=$ & $\overline{\overline{20}}$ & $\overline{\bar{z}} \overline{\bar{c}}$ & $\overline{5=}$ \\
\hline 223 & 2232 & 5432 & 3325 & 4323 & 2232 & 3454 & 553 \\
\hline 3 & 5223 & 5422 & 3225 & $\overline{\overline{43}} \overline{23}$ & $\overline{21}$ & $\overline{\overline{51}} \overline{=1}$ & 5 \\
\hline & 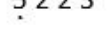 & 5432 & & 4325 & 21 & $?+34$ & ? \\
\hline
\end{tabular}

Gambar 13. Contoh Gelenyu/ Intro Kacapi Wanda Papantunan

\begin{tabular}{|c|c|c|c|c|c|c|c|c|c|c|c|c|c|c|}
\hline ontoh 1 & $\begin{array}{l}\text { Tangan } \\
\text { Kiri }\end{array}$ & $0 \ddot{3}$ & $\ddot{2}$ & 1 & 5 & Contoh 2 & $\overline{05}$ & $0 \overline{5}$ & $\overline{05}$ & $\overline{05}$ & $\overline{05}$ & $\overline{05}$ & $\overline{05}$ & $\overline{05}$ \\
\hline & $\begin{array}{l}\text { Tangan } \\
\text { Kanan }\end{array}$ & $\overline{\overline{1201}}$ & $\ddot{2} \dot{5}$ & $\overline{0 \dot{5}}$ & $0 \dot{5}$ & & $\tilde{2}$ & $\overline{1} \dot{5}$ & 2 & $\overline{340}$ & $\ddot{2}$ & & $\ddot{z}$ & 0 \\
\hline
\end{tabular}

Gambar 14. Contoh Pola Iringan Kacapi Dikemprang dalam Wanda Papantunan

\begin{tabular}{|c|c|c|c|}
\hline dalam rumpaka & 5 & 5 & $m_{5}$ \\
\hline ‘Juragan’ & $\mathrm{Ju}-$ & $\mathrm{ra}-$ & gan \\
\hline dalam rumpaka & 5 & & \\
\hline ‘Gening & Ge- & ning & \\
\hline
\end{tabular}

Contoh penerapan dalam lagu dapat dilihat pada gambar 12 .

\section{Memiliki Gelenyu/ Intro Yang Bawakan Oleh} Musik Pengiring.

Gelenyul intro; merupakan sebuah kalimat melodi khusus yang dimainkan oleh kacapi indung dan suling/ rebab/ biola pada sajian lagu-lagu mamaos, dan oleh kacapi indung, kacapi rincik, dan suling/ rebab/ biola pada sajian lagu wanda panambih. Masingmasing lagu dalam wanda papantunan pada umumnya memiliki melodi gelenyu khusus yang dimainkan sebelum masuk kepada sajian lagu utama. Contoh melodi gelenyu kacapi dalam lagu Papatet dapat dilihat pada gambar 13.
9. Diiringi Oleh Kacapi Dengan Menggunakan Pola Iringan Dikemprang

Dikemprang merupakan salah satu pola iringan dalam kacapi cianjuran, pola iringan tersebut memiliki motif melodi tertentu dalam empat hingga delapan ketuk dalam satu putaran/ kolotomik/ sequence melodi. Pada wanda papantunan, melodi pola iringan dikemprang menggunakan nada dominan 5 (La) dan sub dominan 2 (Mi). Pola iringan dikemprang jika menggunakan pendekatan akor pada musik barat (chord), pola iringan tersebut termasuk ke dalam pola iringan yang menggunakan satu akor saja (one chord). Contoh pola iringan kacapi dikemprang dapat dilihat pada gambar 14 .

Di samping memiliki ciri khas musikal yang tercermin dalam melodi lagu, wanda papantunan juga memiliki struktur penyajian yang berbeda dengan wanda-wanda lainnya (kecuali dengan lagu-lagu wanda jejemplangan yang merupakan pengembangan dari lagu- 
lagu wanda papantunan). Dalam penyajiannya bersama dengan alat musik pengiring, struktur penyajian lagu-lagu wanda papantunan adalah sebagai berikut:

1) Diawali oleh Narangtang (kacapi); merupakan sebuah kalimat melodi yang dimainkan oleh kacapi indung, fungsinya untuk memberikan patokan wilayah nada pada lagu yang akan dimainkan oleh juru mamaos/ panembang/vokalis.

2) Narangtang pantun

3) Gelenyu

4) Lagu utama wanda papantunan hingga selesai.

Sebagai catatan, narangtang pantun disajikan hanya pada sajian pertama dari suatu lagu wanda papantunan. Jika dalam suatu penyajian tembang sunda cianjuran, juru mamaos membawakan dua atau lebih lagu wanda papantunan, maka hanya lagu pertamalah yang diawali oleh lantunan narangtang pantun. Untuk melanjutkan ke lagu selanjutnya, cukup diselingi atau dijembatani oleh gelenyu kacapi dari lagu yang akan dibawakan. Kemudian, jika lagu wanda papantunan merupakan lagu urutan terakhir dalam rangkaian lagu mamaos, maka ketika akan dilanjutkan ke wanda panambih, biasanya diawali dengan melantunkan narangtang pondok dengan menggunakan rumpakal Syair lagu; sumangga urang lajeungkeun.

\section{SIMPULAN}

Munculnya istilah wanda papantunan sebagai salah satu kelompok lagu dalam seni cianjuran, pada awalnya diduga hanya berkaitan dengan sejarah pembentukan materi lagunya. Namun setelah dilakukan analisa musikal melalui notasi lagu, istilah wanda papantunan ternyata memiliki keterkaitan juga dengan dengan aspek-aspek musikal yang terdapat pada lagu-lagunya.

Dalam lagu-lagu wanda papantunan, terdapat aspek-aspek musikal yang meliputi laras, bentuk lagu, kalimat melodi, iringan, dan struktur penyajian lagu yang sering digunakan, muncul atau ditemukan di setiap lagu-lagu dan penyajiannya. Aspekaspek musikal tersebut kemungkinan besar merupakan ciri khas musikal lagu-lagu wanda papantunan, yang berbeda dengan wandawanda lainnya.

Hasil spesifik terkait dengan ciri khas lagu-lagu wanda papantunan, dapat diketahui melalui langkah menelusuri ciri khas musikal lagu-lagu pada wanda lainnya (wanda jejemplangan, wanda dedegungan, wanda rarancagan, wanda kakawen, dan wanda panambih), yang kemudian diikuti oleh proses komparasi terkait dengan ciri khas dari masing-masing wanda, apakah hasilnya spesifik berbeda atau mungkin melodi-melodi yang dianggap sebagai ciri khas suatu wanda juga terdapat dalam wanda lain.

Dengan langkah-langkah penelusuran di atas, sangat memungkinkan akan ditemukan indikator-indikator musikal yang menjadi ciri khas musikal lagu pada wanda-wanda dalam cianjuran, yang kemudian mengarah kepada temuan-temuan yang berkaitan dengan nilai estetika musikal lagu-lagu cianjuran. Nilai estetika musikal dari lagu-lagu cianjuran, saat ini baru teridentifikasi oleh perasaan atau rasa musikal dari masing-masing seniman sesuai dengan pengalaman empiris berkeseniannya, 
namun hal-hal yang berkaitan dengan indikator-indikator musikalnya masih memerlukan kajian yang mendalam.

\section{UCAPAN TERIMAKASIH}

Penulis menyampaikan ucapan terimakasih kepada Lembaga Pusat Penelitian dan Pengabdian Masyarakat (LPPM) Universitas HKBP Nommensen yang telah memberikan support dan bantuan dana penelitian. Tak lupa juga kepada tim pencacah data dalam keterlibatan penelitian di lapangan yaitu Fitria Banjarnahor dan Yohana Margaretta Nababan, keduanya adalah mahasiswa Prodi Seni Musik Universitas HKBP Nommensen Medan.

\section{DAFTAR PUSTAKA}

Edmund-Karl, Prier SJ. (2011). Ilmu Bentuk Musik. Cetakan ke-tiga. Yogyakarta: Pusat Musik Liturgi

Hendrayana, Dian Dienaputra, Reiza Muhtadin, Teddi Nugrahanto, Widyo. (2020). Pelurusan Istilah kawih, Tembang, dan Cianjuran. Panggung: 30 (3), 411424

Hermawan, Deni. (2014). Fenomena Gender dalam Dongkari Lagu-Lagu Tembang Sunda Cianjuran. Panggung: 24 (1), 2538

Kusumadinata, Raden Machjar Angga. (1969). Ilmu Seni Raras. Jakarta: Pradjaparamita

Kutha Ratna, Nyoman. (2015). Estetika Sastra dan Budaya. Cetakan ke-tiga. Yogyakarta: Pustaka Pelajar

Natapradja, Iwan. (2003). Sekar Gending. Bandung: PT. Karya Cipta Lestari.

Sukanda, Enip Atmadinata, R.H.M. Kosasih
Sulaeman, Dadang. (2016). Riwayat Pembentukan dan Perkembangan Cianjuran. Bandung: Dinas Pariwisata dan Kebudayaan Provinsi Jawa BaratYayasan Pancaniti.

Sugiyono. (2012). Metode Penelitian Kuantitatif Kualitatif dan RED. Bandung: Alfabeta. Wiratmadja, Apung S. (1996). Mengenal Seni Tembang Sunda. Bandung: Dinas Pendidikan dan Kebudayaan-CV. Wahana Iptek. 